\title{
Mixed Ratio of Mugwort Chochung and Sugared Garlic for Optimizing Antioxidant Activity Using Response Surface Methodology (RSM)
}

\author{
Jae-Seok Lee ${ }^{1}$, Ae-Jung Kim²* \\ ${ }^{1}$ Department of Alternative Medicine, Kyonggi University, Seoul, Korea \\ ${ }^{2}$ Major of Nutrition Therapy, The Graduate School of Alternative Medicine, Kyonggi University, Seoul, Korea
}

\author{
*Corresponding author: Ae-Jung Kim, Major \\ of Nutrition Therapy, The Graduate School \\ of Alternative Medicine, Kyonggi University, \\ 24, Kyonggidae-ro-9 gil, Seodaemun-gu, \\ Seoul 03752 Korea \\ Tel.: +82 23905012 \\ Fax: +825042461464 \\ Email: aj5249@naver.com
}

Received August 03, 2020

Revised November 17, 2020

Accepted November 25, 2020

Published December 30, 2020

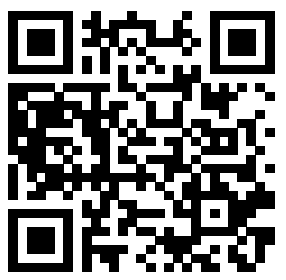

\begin{abstract}
Purpose: The aim of this study is to investigate the safety of mugwort Chochung, sugared garlic (single compound), and the mixture of two (1:1), and find the optimum mixing ratio of the mixture, which can maximize antioxidant activity by response surface methodology (RSM). Methods: We carried out MTT assay to evaluate the safety of each single compound, mugwort Chochung and sugared garlic, and the 1:1 mixture. Independent variables were set mugwort Chochung as $\mathrm{X} 1$, an assay of sugared garlic as X2, and 1 to 2 as a minimum and maximum range of assay by RSM. And, dependent variables were a total polyphenol assay, a total flavonoid assay, a DPPH radical scavenging ability, and an ABTS radical scavenging ability. Results: It did not show any cytotoxicity from each single compound, mugwort Chochung and sugared garlic, and the 1:1 mixture. Also, we found that the optimum mixing ratio of the mixture, which can maximize antioxidant activity, is mugwort Chochung (X1) of 1.96, sugared garlic (X2) of 2, derived from RSM. At the optimal conditions, the predicted characteristic values were: total polyphenol assay of $20.27 \mathrm{mg} \mathrm{TAE} / \mathrm{g}$, total flavonoid assay of $21.02 \mathrm{mg} \mathrm{QE} / \mathrm{g}$, DPPH radical scavenging ability of $85.65 \%$, and ABTS radical scavenging ability of $84.85 \%$. Conclusion: We prepared mugwort Chochung and sugared garlic to expand the use of mugwort and garlic, which are medicinal plants, and confirmed its safety of the mixture. Also, the optimum point for having maximum antioxidant activity was derived from RSM. We anticipate that this study could be useful as a natural functional food ingredient with secured safety.
\end{abstract}

Keywords: Mugwort, Garlic, MTT assay, Antioxidant activities, Response surface methodology

\section{Introduction}

생명체의 대사과정에서 불가피하게 생성되는 활성산소는 세포를 파괴시키는 독성 물질로 $\mathrm{DNA}$, 지질, 단백질에 손상을 주어 세포의 정상적인 기능 유지를 어렵게 한다(Kim et al., 2015), 활성산소의 증 가는 산화적 스트레스(oxidative stress)를 유발하여 세포에 손상을 입 히며 이로 인해 당뇨나 심혈관계 질환, 신경계 질환 및 $\mathrm{DNA}$ 손상에 따른 암(cancer) 유발, 노화촉진 등 다양한 형태의 병리적 이상을 초 래한다(Powers et al., 2010). 따라서 활성산소를 증가시키는 요인을 제거하고 항산화 물질이 많이 함유된 식품을 충분히 섭취해야 한다.
하지만 대체 보조식품에 합성물질이 이용되면서 발생하는 문제점 때 문에 국내에서는 천연자원 또는 천연물질의 2 차 대사물을 통해 생산 되는 생리활성 물질에 대한 관심이 증대되고 천연물질에 대한 연구가 활발히 진행되고 있다(Han et al., 2012; Jang et al., 2011).

삼국유사에는 쑥과 마늘에 관하여 "곰과 호랑이에게 신령한 쑥 한 줌과 마늘 20 개를 주며 말하기를, 너희들이 이것을 먹고 백일 동안 햇 빛을 보지 않으면 사람이 될 것이다(時种遺靈艾一炷 蒜二十枚 日 爾 輩食之 不見日光百日 更得人形"라고 기록되어 있는 것으로 보아, 쑥 과 마늘은 곰이 사람이 되는 매개물(媒介物) 구실을 하고 있을 만큼 예로부터 중요한 약용식물로 이용되었다 (Kim, 2018). 


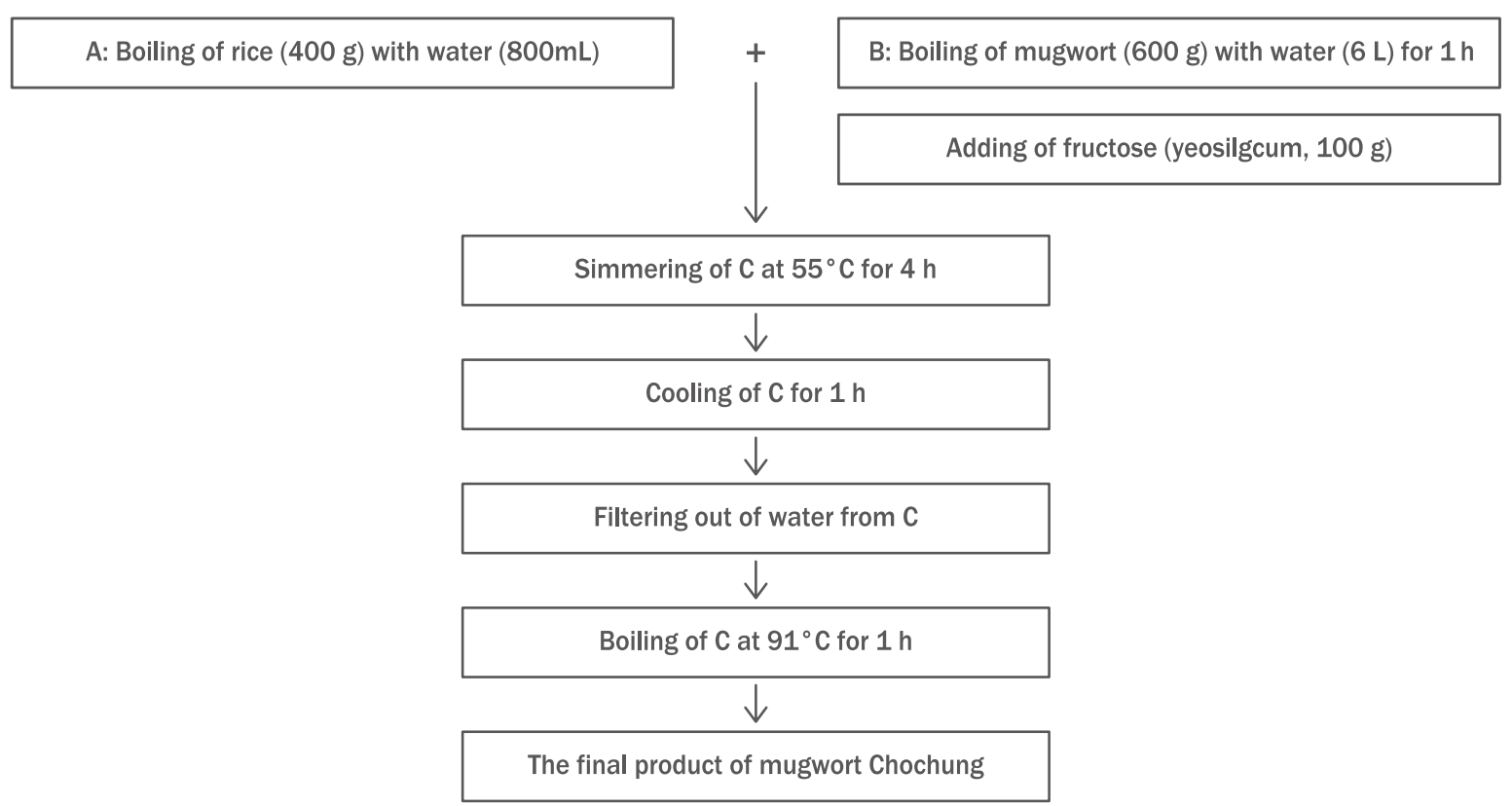

Figure 1. Manufacturing procedure for mugwort Chochung.

쑥(Mugwort)은 국화과(Compositae)에 속하며 한국, 일본, 중국 등 초목지에서 흔하게 볼 수 있는 다년생 식물로 품종이 약 400여종 으로 분화되어 있다(Lee et al., 2000; Seo et al., 2011). 참쑥, 개똥 쑥, 쓴쑥, 사자발쑥 등 다양한 품종 중에서 인진쑥과 약쑥이 약용식 물로 가장 많이 이용되고 있다(Choi et al., 2005). 인진쑥(Artemisia capillaris Thunb)은 사철쑥, 애탕쑥으로도 불리며 필수 지방산과 회 분, 섬유소가 풍부하여 체중조절을 위한 식품으로 권장되는 것으로 보고되었으며, 칼슘과 칼륨의 함량이 높고 vitamin $\mathrm{A}$ 와 $\mathrm{C}$ 의 함량은 일반 야채류를 포함한 산나물류 중에서 가장 높은 것으로 알려져 있 다(Ahn, 2000; Kim et al., 2007). 인진쑥은 항균(Drachenberg et al., 2004; Jaggi et al., 2005; Markowitz et al., 2000), 항암(Chu et al., 1999; Peters et al., 1977), 항산화(Pal et al., 2005; Ram et al., 1986), 항염증(Liotta, 1986)등의 효능이 있으며, 간 보호 효과 (Han et al., 1999; Scherer, 1984)와 항알르레기 효능(Chun et al., 2001)이 밝혀지면서 인진쑥의 기능성 물질이 주목 받고 있다. 그러나 쑥 특유의 향과 맛으로 식품 자체로의 활용도는 낮은 편이어서 식품 자체로 섭취할 방안의 마련이 필요한 실정이다.

마늘(Allium sativum L.)은 백합과(Liliaceae)의 Allium속 식물 로 중앙아시아와 지중해 연안 지역이 그 원산지로 추정되며(Byun et al., 2001), 강한 냄새를 제외하고는 100 가지 이로움이 있다고 하여 일해백리(一害百利)라고 부르기도 한다. 또한 2002년 미국 타임지에 서는 마늘을 세계 10 대 건강식품으로 선정하였으며, 마늘이 항암효 과가 있는 것으로 알려져 많은 연구가 진행되고 있다(Shashikanth et al., 1981; Son et al., 1990). 마늘이 파쇄될 때 마늘의 유기 황화
합물의 주요성분인 alliin이 alliinase의 작용에 의해 allicin으로 전환 되는데, allicin은 마늘 생리활성의 주성분으로 알려져 있다(Choi et al., 2008). 마늘에는 향기 성분과 전구물질의 생성 및 분해에 여러 종 류의 효소가 관여하고 있는 것으로 알려져 있다(Carson, 1987). 향 기 성분으로는 allicin은 신선한 마늘 냄새(Stoll \& Seebek, 1951), disulfide 및 trisulfide는 조리된 마늘의 향미(Cavallito et al., 1944), allyl mercaptan과 diallyl disulfide는 마늘 섭취 후 풍기는 강한 냄새 이다(Jacobsen et al., 1964). 또한 마늘은 면역력 증진(Sung, 2009), 항산화(Block, 1985; Jain et al., 1975), 항균(Shin et al., 1999), 항 암(Shashikanth et al., 1981; Son et al., 1990), 간 기능 개선(Kim et al., 2005a; Kwon, 2003), 심혈관 질환의 개선효과(Rho et al., 2000; Kim et al, 2005b) 등이 있는 것으로 보고된 바 있어 천연 건 강 기능성 식품으로도 활용도가 높다(Park et al., 2012).

그러나 마늘 역시 특유의 향과 맛이 있어 최근에는 이러한 부정적 인 면의 개선을 위해 산업계에서는 숙성 마늘로 제조되어 소비가 증 가하였다. 특히 숙성을 거치면서 총 폴리페놀, 플라보노이드 함량이 증가하고 또 다른 기능성을 갖는 것으로 보고된 바 있다(Jeong et al., 2014). 한편, 현대인들의 골다공증, 당뇨병 발병률이 증가되면서 설 탕 등의 단당류 섭취를 줄이고 곡물을 통한 다당류 섭취의 필요성이 중요시되고 있는데, 특히 조청은 음식의 맛을 내면서 체내에 유용한 당분을 효과적으로 공급할 수 있어 그 사용빈도와 범위를 다양화할 수 있는 식재료 중 하나이다(Choi \& Park, 2015).

따라서 본 연구에서는 약용식물로 알려진 인진쑥과 마늘의 이용성 을 높이고자 쑥 조정과 당침마늘로 제조한 후 안전성을 먼저 평가하 


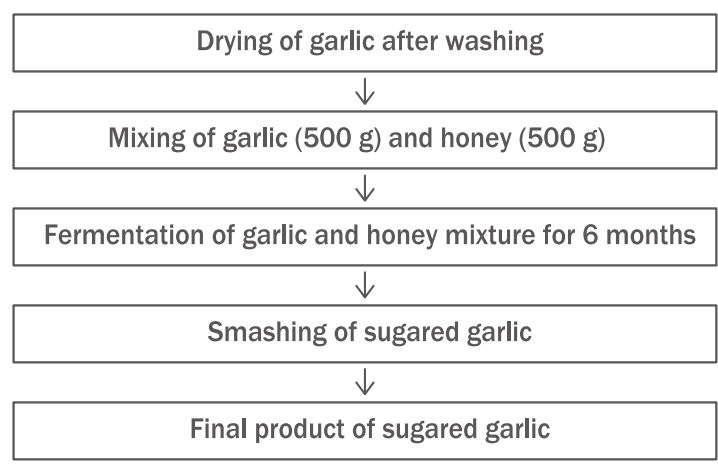

Figure 2. Manufacturing procedure for sugared garlic.

였고 반응표면분석법(response surface methodology, RSM)을 이용 하여 항산화 효능이 최대로 발현되는 최적혼합비율을 도출하고자 하 였다.

\section{Methods}

\section{1. 실험재료}

본 실험에 사용된 인진쑥과 꿀은 동광 종합물산에서 구입하였고 찹 쌀은 경남 합천군의 가현미곡에서 구입하였다. 엿기름은 광주시에 있 는 자연과 사람에서 구입하였고 마늘은 경남 남해농협에서 구입하여 시료로 사용하였다.

\section{2. 쑥 조청과 당침마늘 제조}

쑥 조청은 Bae et al. (2012)의 연구방법을 참고하여 제조하였다. 찹쌀 $400 \mathrm{~g}$ 에 물 $800 \mathrm{~mL}$ 를 넣고 고두밥을 만들어 식혀준 뒤, 인진 쑥 $600 \mathrm{~g}$ 에 물 $6000 \mathrm{~mL}$ 를 넣고 $1 \mathrm{~h}$ 끓여서 쑥 건더기는 잘 걸러내어 찹쌀로 만든 고두밥과 엿기름 $100 \mathrm{~g}$ 을 넣어 잘 섞이도록 저어준 후, $55^{\circ} \mathrm{C}$ 의 항온기에서 $4 \mathrm{~h}$ 동안 당화하였다. 당화액을 삼베 자루에 넣어 꼭 짜서 찌꺼기는 버리고 원액을 분리하여 시료 내의 온도가 $91^{\circ} \mathrm{C}$ 에 서 $1 \mathrm{~h}$ 저어주면서 가열하여 쑥 조청을 제조하였다(Figure 1).

당침마늘은 마늘 $500 \mathrm{~g}$ 을 껍질을 제거한 뒤 깨끗이 씻고 건조한 후, 무게 대비 $1: 1$ 아카시아 꿀 $500 \mathrm{~g}$ 에 혼합하여 유리 용기에 밀봉 하여 통풍이 잘되는 그늘진 곳에서 6 개월 간 보관하여 사용하였다 (Figure 2).

\section{2. 안전성 평가}

1) 추출물 제조

단일물(쑥 조청, 당침마늘)과 $1: 1$ 혼합물(쑥 조청과 당침마늘)의 세 포독성 측정을 위해 각 시료 무게 대비 각각 10 배 부피의 증류수를 첨가한 후 환류냉각관을 부착한 $80^{\circ} \mathrm{C}$ 의 heating mantle (HM250C; Sercrim Lab Tech, Korea)에서 $2 \mathrm{~h}$ 추출한 후 3회 여과(No. 3, Whatman, England)하여 분석용 시료로 사용하였다.

\section{2) 세포배양}

본 연구에 사용된 RAW 264.7 세포는 한국세포주은행(Korean Cell Line Bank: KCLB, Korea)에서 구입하여 사용하였다. Dulbecco's modified Eagle's medium (Gibco, USA)에 10\%의 fetal bovine serum (FBS, Gibco, USA)과 1\% penicillin-streptomycin (Gibco)을 첨가하여 배지로 사용하였으며 $37^{\circ} \mathrm{C}, 5 \% \mathrm{CO} 2$ 조건으로 humidified incubator (Thermo Fisher Scientific, USA)에서 배양하였다.

\section{3) MTT assay}

단일물(쑥 조청, 당침마늘)과 $1: 1$ 혼합물(쑥 조청과 당침마늘) 의 세포독성을 평가하기 위해 RAW 264.7 세포를 $5 \times 10^{4}$ cells/ well의 농도로 96 well plate에 분주하여 $37^{\circ} \mathrm{C}, 5 \% \mathrm{CO}_{2}$ 조건으 로 humidified incubator(Thermo Fisher Scientific, USA)에 $24 \mathrm{~h}$ 동안 배양하였다. 배양 후 각 시료를 $500 \mu \mathrm{g} / \mathrm{mL}, 1,000 \mu \mathrm{g} / \mathrm{mL}$,

Table 1. Independent variables and their coded levels and actual values used for optimization

\begin{tabular}{lcc}
\hline Samples & Mugwort Chochung $\left(X_{1}\right)$ & Sugared garlic $\left(X_{2}\right)$ \\
1 & 2.00 & 1.00 \\
2 & 1.50 & 1.50 \\
3 & 1.00 & 2.00 \\
4 & 1.50 & 2.00 \\
5 & 2.00 & 1.50 \\
6 & 1.50 & 1.50 \\
7 & 1.00 & 1.00 \\
9 & 2.00 & 2.00 \\
11 & 1.00 & 1.50 \\
\hline
\end{tabular}


$2,500 \mu \mathrm{g} / \mathrm{mL}, 5,000 \mu \mathrm{g} / \mathrm{mL}$ 농도로 희석하여 처리하고 $37^{\circ} \mathrm{C}, 5 \%$ $\mathrm{CO}_{2}$ 조건으로 humidified incubator (Thermo Fisher Scientific) 에 $24 \mathrm{~h}$ 동안 배양하였다. $24 \mathrm{~h}$ 배양 후 상층액을 제거하고 $1 \mathrm{mg} /$ $\mathrm{mL}$ 의 3-(4,5-Dimeth ylthiazol-2-yl)-2,5-diphenyltetrazolium Bromide (MTT; Invirtrogen, USA)를 각 well에 첨가한 뒤 $4 \mathrm{~h}$ 동 안 반응시켰다. 반응 후 MTT 용액을 제거하고 dimethyl sulfoxide (DMSO; Daejung, Korea)를 $300 \mu \mathrm{L} /$ well에 분주하여 formazan crystal을 용해시킨 뒤 $540 \mathrm{~nm}$ 흡광도로 측정하였고, 결과는 대조군 에 대한 세포 생존율을 백분율로 표시하였다.

\section{3. 반응표면분석법(RSM)을 이용한 실험설계}

\section{1) 혼합 비율 설정}

쑥 조청과 당침마늘의 최적 혼합비율을 도출하기 위해 반응표면 분석법(response surface method, RSM)의 중심합성계획법(central composite design, $\mathrm{CCD}$ )에 따라 실험을 설계하였다. 독립변수로는 인진쑥 조청 $(\mathrm{X} 1)$ 과 당침마늘(X2)의 함량으로 설정하였고, 각 함량 의 범위는 예비실험을 바탕으로 각 요인의 최소 및 최대 범위를 쑥 조청(1-2 g), 당침마늘(1-2 g)로 설정하였다. RSM을 이용하여 설 계된 혼합비율은 Table 1에 제시된 바와 같으며, 종속변수로는 total polyphenol 함량, total flavonoid 함량, DPPH radical 소거능, ABTS radical 소거능으로 설정하였다.

\section{2) 추출물 제조}

$\mathrm{RSM}$ 에 의해 설계된 11 개 샘플의 항산화 활성 측정 시료 제조를 위 해 쑥 조청과 당침마늘을 무게 대비 각각 10 배의 증류수를 첨가한 후 환류냉각관을 부착한 $80^{\circ} \mathrm{C}$ 의 heating mantle (HM250C; Sercrim Lab Tech, Korea)에서 $2 \mathrm{~h}$ 추출시킨 후 3회 여과(No. 3, Whatman, England)하여 쑥 조청과 당침마늘 시료를 제조하였고 증류수 $10 \mathrm{~mL}$ 에 쑥 조청 시료와 당침마늘 시료를 각 비율대로 첨가하여 분석용 시 료로 사용하였다.

\section{4. 항산화 활성 측정}

\section{1) Total polyphenol 함량 측정}

$\mathrm{RSM}$ 에 의해 설계된 11 개 샘플의 total polyphenol함량은 $\mathrm{F}-\mathrm{C}$ 시 약을 사용하는 Singleton \& Rossi (1995)의 방법을 변형하여 측정하였 다. 추출물 $350 \mu \mathrm{L}$ 에 $50 \%$ Folin-Ciocalteu (Sigma-Aldrich, USA) 시 약 $70 \mu \mathrm{L}$ 를 가하여 $3 \mathrm{~min}$ 간 정치한 후, $2 \%(\mathrm{w} / \mathrm{v}) \mathrm{Na}_{2} \mathrm{CO}_{3}$ 용액 350 $\mu \mathrm{L}$ 를 첨가하여 $1 \mathrm{~h}$ 반응시킨 후, ELISA microplate reader (Infinite M200 pro Nanoquant; Tecan Austria GmbH, Austria)를 이용하여 $420 \mathrm{~nm}$ 에서 흡광도를 측정하였다. 총 폴리페놀 함량은 tannic acid를 이용하여 작성한 표준 곡선으로부터 구하였다.

\section{2) Total flavonoid 함량 측정}

Total flavonoid 함량은 Davis (1947)의 방법을 변형하여 측

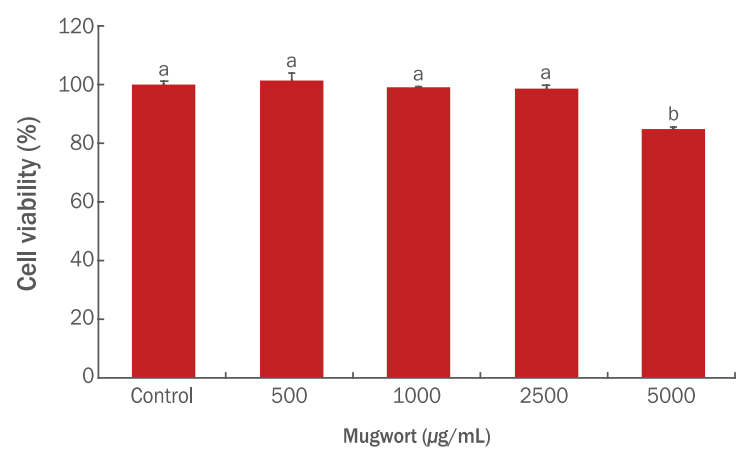

Figure 3. Cell viability of mugwort Chochung extracts using MTT assay.

Mugwort Chochung extracts were treated at different concentrations $(500 \mu \mathrm{g} / \mathrm{mL}, 1,000 \mu \mathrm{g} / \mathrm{mL}, 2,500 \mu \mathrm{g} / \mathrm{mL}$, and $5,000 \mu \mathrm{g} / \mathrm{mL}$ ) in RAW 264.7 cells, data were presented as mean $\pm S D(n=4)$, and significant differences were determined using the Duncan's multiple range test at $p<0.05$.

정하였다. 추출물 $70 \mu \mathrm{L}$ 에 diethylene glycol (Daejung) $700 \mu \mathrm{L}$ 를 첨가하고 다시 $1 \mathrm{~N}-\mathrm{NaOH}$ 용액 $7 \mu \mathrm{L}$ 를 첨가한 후 $37^{\circ} \mathrm{C}$ 에서 $1 \mathrm{~h}$ 반응시킨 후, ELISA microplate reader (Infinite M200 pro Nanoquant; Tecan Austria GmbH,)를 이용하 여 $420 \mathrm{~nm}$ 에서 흡광도를 측정하였다. 총 플라보노이드 함량 은 quercetin을 이용하여 작성한 표준 곡선으로부터 구하였다.

\section{3) $\mathrm{DPPH}$ radical 소거능 측정}

1, 1-diph enyl-2-picrylhy drazyl (DPPH, Sigma-Aldrich) radical 소거능은 Blois (1958) 변법에 의하여 다음과 같이 실시하였다. 시료 $100 \mu \mathrm{L}$ 에 $1.5 \times 10^{-4} \mathrm{M} \mathrm{DPPH}$ 용액 $100 \mu \mathrm{L}$ 을 가하여 실온의 암실에 서 $30 \mathrm{~min}$ 간 정치한 후, ELISA microplate reader (Infinite M200 pro Nanoquant; Tecan Austria $\mathrm{GmbH}$ 를 이용하여 $517 \mathrm{~nm}$ 에서 흡광도를 측정하였다.

\section{4) ABTS radical 소거능 측정}

2,2'-azino-bis-3-ethylbenzo-thiazoline-6-sulfonic acid (ABTS, Sigma-Aldrich) radical 소거능은 Fellegrin et al. (1998)의 방법으로 측 정하였다. ABTS $7.4 \mathrm{mM}$ 과 potassium persulphate (Daejung, Korea) $2.6 \mathrm{mM}$ 을 같은 비율로 섞어 하루 동안 암소에 방치하여 ABTS 양이 온을 형성시킨 후 $732 \mathrm{~nm}$ 에서 흡광도 값이 $0.70 \pm 0.02$ 가 되도록 가 하여 $1 \mathrm{~h}$ 정치한 후, ELISA microplate reader (Infinite M200 pro Nanoquant; Tecan Austria $\mathrm{GmbH}$ )를 이용하여 $732 \mathrm{~nm}$ 에서 흡광도를 측정하였다.

\section{5. 통계처리}

실험 자료의 분석 및 최적화는 Design Expert 10 (Stat-Ease, Inc., 


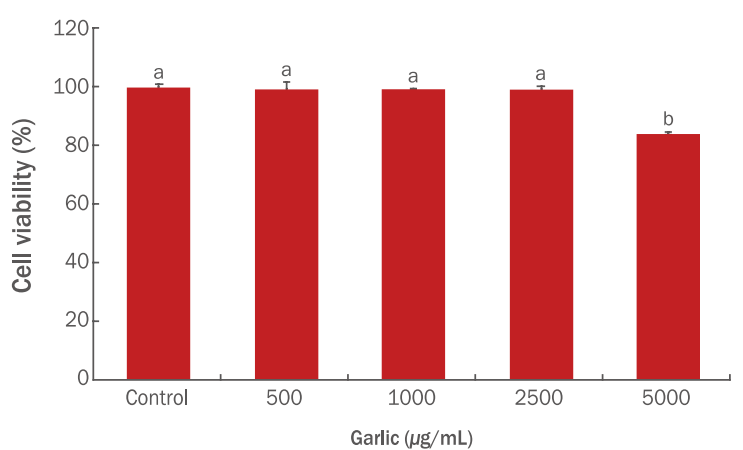

Figure 4. Cell viability of sugared garlic extracts using MTT assay.

Sugared garlic extracts were treated at different concentrations (500 $\mu \mathrm{g} / \mathrm{mL}, 1,000 \mu \mathrm{g} / \mathrm{mL}, 2,500 \mu \mathrm{g} / \mathrm{mL}$, and 5,000 $\mu \mathrm{g} / \mathrm{mL}$ ) in RAW 264.7 cells, data were presented as mean $\pm S D(n=4)$, and significant differences were determined using the Duncan's multiple range test at $p<0.05$.

USA) Program의 ANOVA test와 회귀분석을 이용하였으며, 모델 의 적합성은 F-test로 유의성을 검정하였다. 이외 모든 자료는 SPSS statistics 21 (SPSS Institute, USA)을 이용하여 평균과 표준편차 를 구하였으며, 샘플 간의 유의성은 ANOVA를 실시한 후, Duncan's multiple range test로 각 샘플의 평균차이에 대한 사후 검정을 유의수 준 $5 \%$ 에서 실시하였다.

\section{Results and Discussion}

\section{1. 안전성 평가}

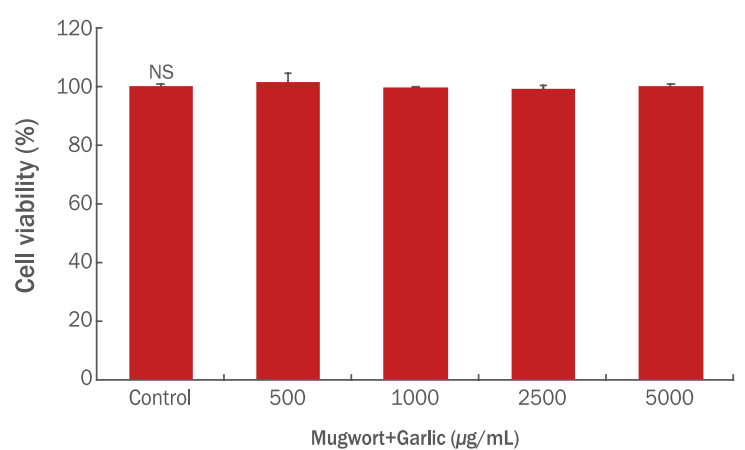

Figure 5. Cell viability of mugwort Chochung and sugared garlic extracts using MTT assay.

Mugwort Chochung and sugared garlic extracts were treated using different concentrations $(500 \mu \mathrm{g} / \mathrm{mL}, 1,000 \mu \mathrm{g} / \mathrm{mL}, 2,500 \mu \mathrm{g} / \mathrm{mL}$, and $5,000 \mu \mathrm{g} / \mathrm{mL}$ ) in RAW 264.7 cells and data are presented as mean $\pm S D(n=4)$. NS, not significant.

본 연구에 사용된 단일물(쑥 조청, 당침마늘)과 $1: 1$ 혼합물(쑥 조청 과 당침마늘)을 농도별(500, $1000,2500,5000 \mu \mathrm{g} / \mathrm{mL}$ )로 RAW 264.7 세포에 처리하여 세포 생존율을 측정하였으며, 그 결과는 Figure 3, Figure 4, Figure 5에 제시한 바와 같다. 쑥 조청, 당침마늘, 쑥 조청과 당침마늘 혼합 시료 모두 $5000 \mu \mathrm{g} / \mathrm{mL}$ 농도까지 대조군과 같거나 $80 \%$ 이상의 세포 생존율을 보여 특이한 세포독성은 없는 것으로 나타났 다. Kim et al. (2009)의 연구에서 마늘 추출물의 세포독성 결과, 1000 $\mu \mathrm{g} / \mathrm{mL}$ 농도에서 70-80\%의 세포생존율을 보여 본 연구 결과와 유사 하였다.

\section{2. 항산화 효능}

1) Total polyphenol 함량

Table 2. Antioxidant activities of mugwort Chochung (X1) and sugared garlic (X2) by response surface methodology (RSM)

\begin{tabular}{lcccccc}
\hline Samples & $\begin{array}{c}\text { Mugwort } \\
\text { Chochung }\left(\mathrm{X}_{1}\right)\end{array}$ & $\begin{array}{c}\text { Sugared } \\
\text { garlic }\left(\mathrm{X}_{2}\right)\end{array}$ & $\begin{array}{c}\text { Total polyphenol } \\
\text { content } \\
\left.\left(\mathrm{mg} \mathrm{TAE}^{1}\right) / \mathrm{g}\right)\end{array}$ & $\begin{array}{c}\text { Total flavonoid } \\
\text { content } \\
\left.\left(\mathrm{mg} \mathrm{QE}^{2}\right) / \mathrm{g}\right)\end{array}$ & $\begin{array}{c}\text { DPPH radical } \\
\text { scavenging } \\
\text { activity (\%) }\end{array}$ & $\begin{array}{c}\text { ABTS radical } \\
\text { scavenging } \\
\text { activity }(\%)\end{array}$ \\
\hline 1 & 2.00 & 1.00 & 17.93 & 16.03 & 74.82 & 68.80 \\
2 & 1.50 & 1.50 & 16.76 & 15.70 & 75.84 & 74.01 \\
3 & 1.00 & 2.00 & 18.87 & 18.58 & 80.41 & 76.60 \\
4 & 1.50 & 2.00 & 18.20 & 19.72 & 77.10 & 76.35 \\
5 & 1.00 & 1.50 & 19.11 & 17.61 & 79.86 & 77.30 \\
6 & 1.50 & 1.50 & 17.17 & 16.08 & 77.68 & 75.80 \\
7 & 1.00 & 1.00 & 11.33 & 10.83 & 60.05 & 57.79 \\
10 & 2.00 & 2.00 & 21.02 & 20.28 & 84.47 & 82.55 \\
11 & 1.00 & 1.50 & 15.87 & 11.69 & 67.68 & 73.42 \\
\hline
\end{tabular}

${ }^{1}$ TAE, tannic acid equivalent.

${ }^{2)} \mathrm{QE}$, quercetin acid equivalent. 

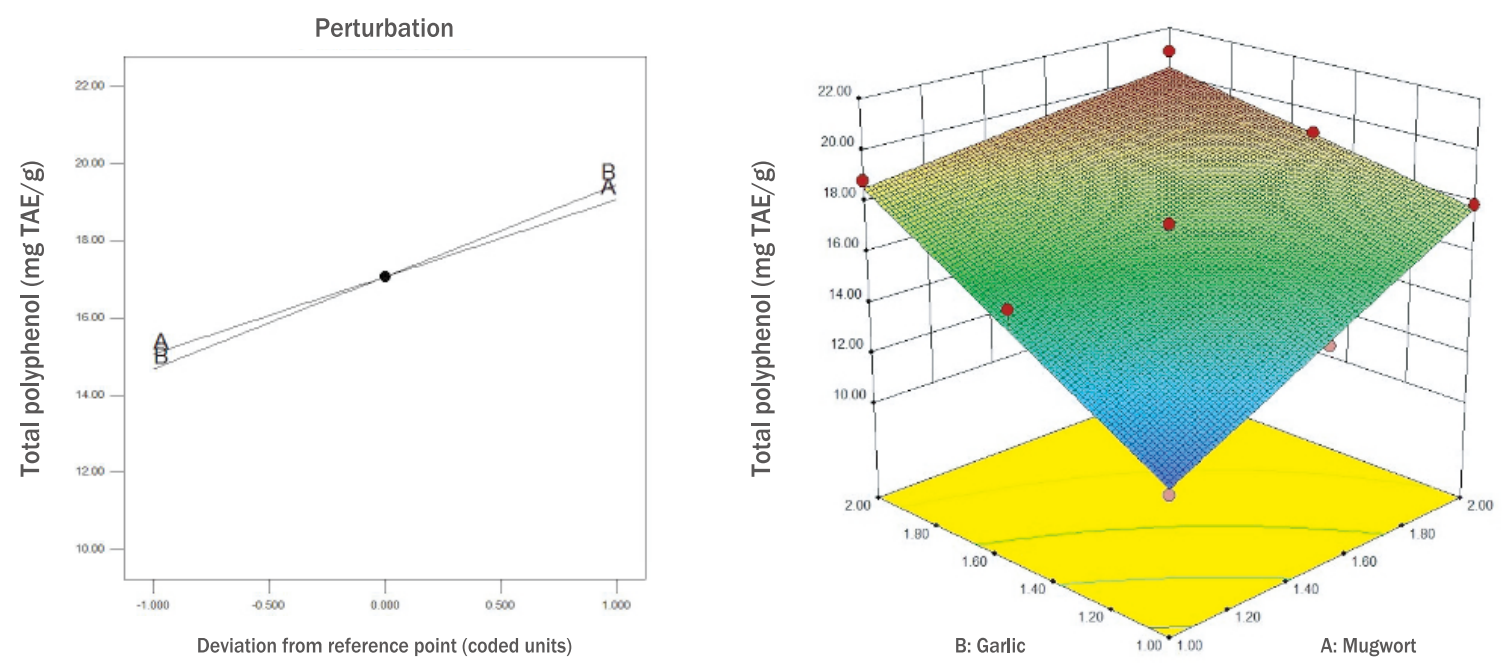
Figure 6. Perturbation plot and response surface plot for the effect of mugwort Chochung (A) and sugared garlic (B) on the total
polyphenol content.

식물의 항산화 물질로 잘 알려진 폴리페놀은 체내의 활성산소를 자 유 라디칼로 안정시켜 산화 스트레스로 인한 손상을 예방하는 효과가 있다(Jung et al., 2019). 따라서 본 연구에서는 쑥 조청과 당침마늘 혼 합물의 항산화 관련 성분을 확인하기 위해 RSM에 의해 설계된 11개 샘플의 총 폴리페놀 함량을 측정하였다. 측정 결과는 2 에, 반응표면 회귀분석은 Table 3 에 제시하였다.

쑥 조청 $(\mathrm{A})$ 과 당침마늘 $(\mathrm{B})$ 혼합물의 total polyphenol 함량 측정 결 과, $11.33-21.02 \mathrm{mg} \mathrm{TAE} / \mathrm{g}$ 범위를 보였는데, 8번 샘플(쑥 조청2, 당 침마늘2)이 $21.02 \mathrm{mg} \mathrm{TAE} / \mathrm{g}$ 으로 가장 높았고, 7번 샘플(쑥 조청1, 당침마늘1)이 $11.33 \mathrm{mg} \mathrm{TAE} / \mathrm{g}$ 으로 가장 낮게 나타났다. 독립변수 간에 선형효과와 곡선효과가 나타나는 quadratic model이 선정되었 고, 결정계수 $\mathrm{R}^{2}$ 값은 0.9353 로 모델에 대한 높은 신뢰도를 보였으며, $p<0.0001$ 로 $5 \%$ 이내에서 유의적인 결과를 보여 모델에 대한 적합성이 인정되었다. Figure 6 에 제시된 perturbation plot에서 쑥 조청(A)과 당침마늘(B)의 함량이 증가할수록 total polyphenol 함량은 유의적으로 증가하였으며, 회귀식에 따라 쑥 조청(A)보다 당침마늘(B)의 첨가량이 total polyphenol 함량에 더 큰 영향을 미치는 것으로 나타났다.

Jang et al. (2008)의 연구에서 생마늘의 총 폴리페놀 함량은 3.7 $\mathrm{mg} \mathrm{TAE} / \mathrm{g}$, 흑마늘은 $10 \mathrm{mg} \mathrm{TAE} / \mathrm{g}$ 이었으며, 생마늘에 비해 흑마늘 의 총 폴리페놀 함량이 2.5 배 이상 높은 것으로 나타나 마늘의 숙성 과 정에서 연화 된 마늘 조직에 기인하여 폴리페놀 함량이 증가한 것으로 보인다. 또한 쑥 분말을 첨가한 양갱의 품질특성에 관한 연구(Choi \& Lee, 2013)에서 쑥 분말의 첨가량이 많을수록 총 폴리페놀 함량이 증 가하는 것으로 보고하였는데, 본 연구에서 쑥 조청의 함량이 증가할수 록 혼합물의 총 폴리페놀 함량이 증가한 결과와 유사한 것을 알 수 있 었다.

\section{2) Total flavonoid 함량}

$\mathrm{RSM}$ 에 의해 설계된 쑥 조청과 당침마늘 혼합물 11 개 샘플의 총 플 라보노이드 함량 측정 결과는 Table 2에, 반응표면 회귀분석은 Table 3 에 제시하였다. 쑥 조청 $(\mathrm{A})$ 과 당침마늘(B) 혼합물의 total flavonoid 함량 측정 결과, $10.83-20.28 \mathrm{mg} \mathrm{QE} / \mathrm{g}$ 범위를 보였는데, 8번 샘플 (쑥 조청2, 당침마늘2)이 $20.28 \mathrm{mg} \mathrm{QE} / \mathrm{g}$ 으로 가장 높았고, 7번 샘플 (쑥 조청1, 당침마늘1)이 $10.83 \mathrm{mg} \mathrm{QE} / \mathrm{g}$ 으로 가장 낮게 나타났다. 독립변수가 각각 작용하여 선형효과만 존재하는 linear model이 선 정되었고, 결정계수 $\mathrm{R}^{2}$ 값은 0.8685 로 모델에 대한 높은 신뢰도를 보 였으며, $p<0.0001$ 로 $5 \%$ 이내에서 유의적인 결과를 보여 모델에 대 한 적합성이 인정되었다. Figure 7에 제시된 perturbation plot에서 쑥 조청 $(\mathrm{A})$ 과 당침마늘 $(\mathrm{B})$ 의 함량이 증가할수록 total flavonoid 함량 은 유의적으로 증가하였으며, 회귀식에 따라 쑥 조청(A)보다 당침마 늘(B)의 첨가량이 total flavonoid 함량에 더 큰 영향을 미치는 것으로 나타났다.

마늘 젤리의 이화학적 품질 특성에 관한 연구(Jung et al. 2009)에 서 생마늘 보다 흑마늘 추출액에서 총 플라보노이드 함량이 더 높게 나타났는데, 이는 마늘의 숙성 과정에서 플라보노이드 함량이 증가한 것으로 생각되며, 본 연구에서도 당침마늘이 첨가된 혼합물의 플라 보노이드 함량은 높게 나타났다. 또한 인진쑥 추출물을 첨가하여 제 조한 식혜의 품질 특성 및 항산화 활성에 대한 연구(Song \& Hwang, 2016)에서 인진쑥 비율이 높아질수록 식혜의 총 플라보노이드 함량 이 증가하였는데, 본 연구에서 쑥 조청의 함량이 증가할수록 혼합물 의 총 플라보노이드 함량이 증가한 결과와 유사한 것을 알 수 있었다. 

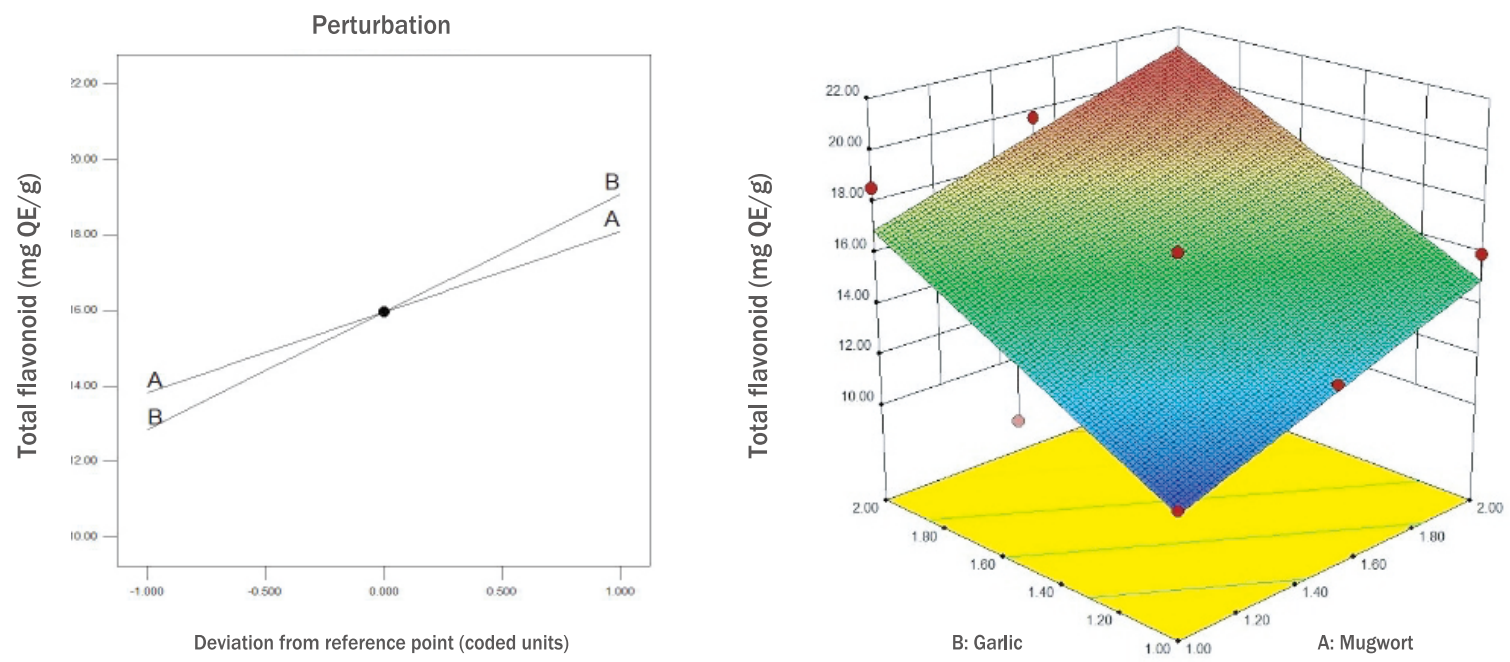

Figure 7. Perturbation plot and response surface plot for the effect of mugwort Chochung (A) and sugared garlic (B) on the total flavonoid content.
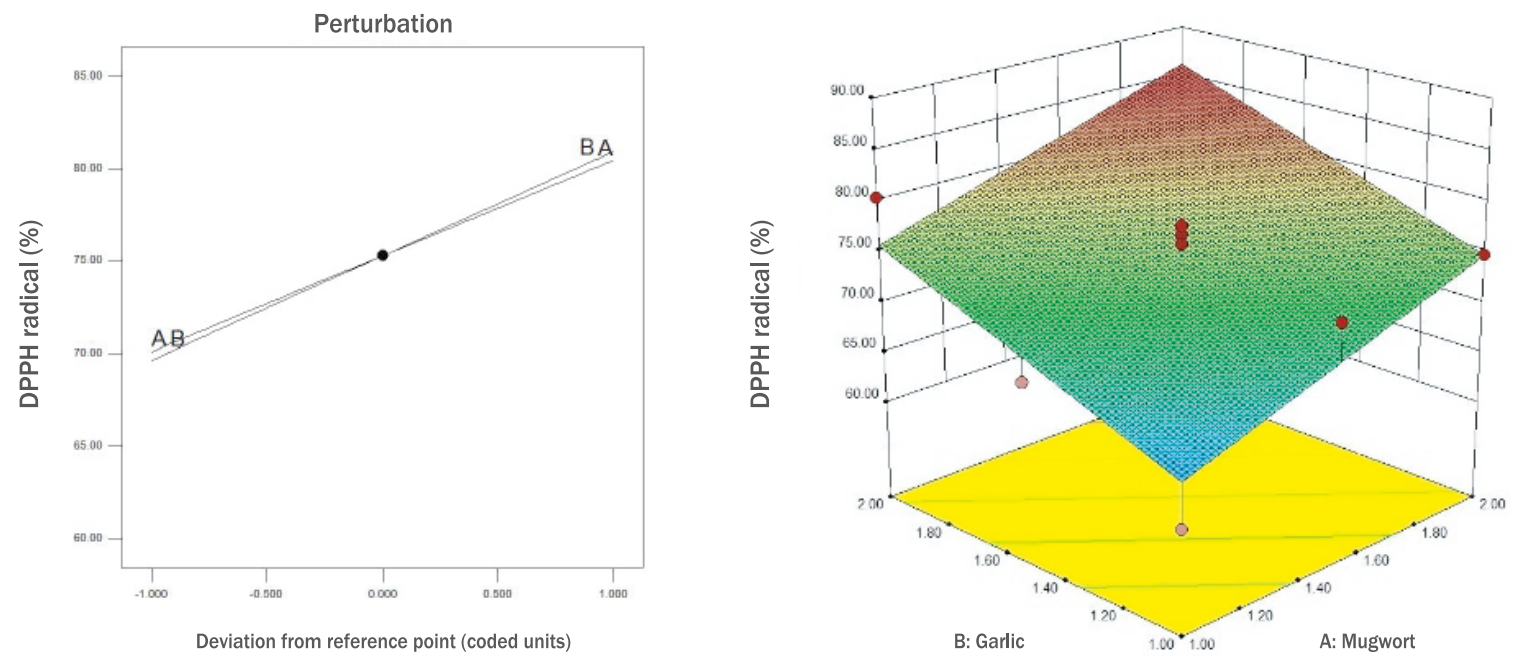

Figure 8. Perturbation plot and response surface plot for the effect of mugwort Chochung (A) and sugared garlic (B) on the DPPH radical scavenging activity.

DPPH, 2,2-diphenyl-1-picrylhydrazyl.

Table 3. Analysis of the predicted model equation for the antioxidant activities of $X_{1}$ and $X_{2}$

\begin{tabular}{|c|c|c|c|c|c|c|}
\hline Response & Model & Mean & $\mathrm{R}^{21)}$ & $F$-value & $p$-value & Polynomial equation ${ }^{2)}$ \\
\hline Total polyphenol content & Quadratic & $17.07 \pm 0.94$ & 0.9353 & 49.20 & $<0.0001$ & $17.07+42.00 \mathrm{~A}+2.39 \mathrm{~B}-1.11 \mathrm{AB}$ \\
\hline Total flavonoid content & Linear & $15.95 \pm 0.87$ & 0.8685 & 34.03 & $<0.0001$ & $15.95+2.12 A+3.11 B$ \\
\hline $\begin{array}{l}\text { DPPH radical scavenging } \\
\text { activity }\end{array}$ & Linear & $80.49 \pm 3.87$ & 0.9177 & 19.53 & $<0.0007$ & $75.27+5.17 A+5.64 B$ \\
\hline $\begin{array}{l}\text { ABTS radical scavenging } \\
\text { activity }\end{array}$ & Linear & $71.08 \pm 0.80$ & 0.9850 & 295.27 & $<0.0001$ & $71.08+5.64 A+8.59 B$ \\
\hline
\end{tabular}

1) $0 \leq R^{2} \leq 1$, indicates the regression line to fix the model

${ }^{2}$ Coded equation (the levels of the factor are coded as +1 -1).

$\mathrm{X} 1$, mugwort Chochung; $\mathrm{X}$, sugared garlic. 

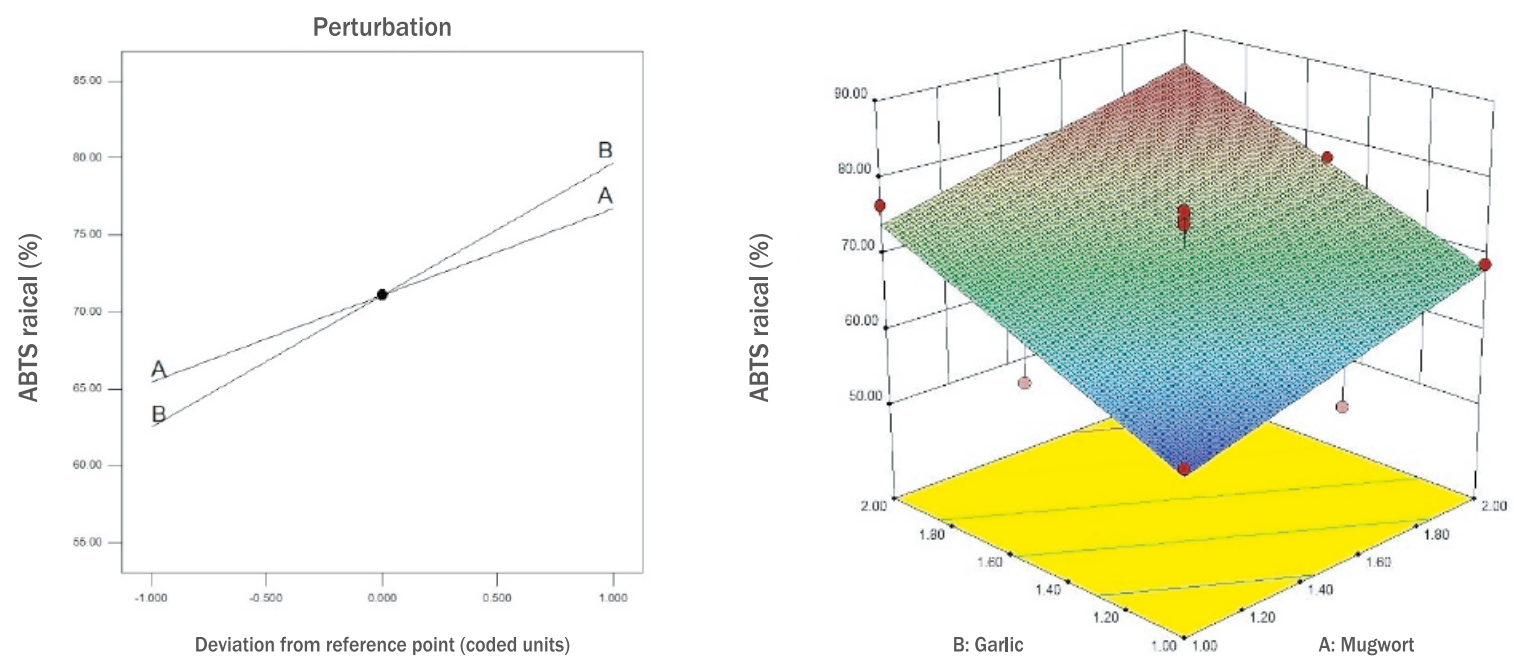

Figure 9. Perturbation plot and response surface plot for the effect of mugwort Chochung (A) and sugared garlic (B) on the ABTS radical scavenging activity.

ABTS , 2, 2'-Azino-Bis-3-ethylbenzothiazoline-6-sulfonic acid.

\section{3) $\mathrm{DPPH}$ radical 소거능}

$\mathrm{RSM}$ 에 의해 설계된 쑥 조청과 당침마늘 혼합물 11 개 샘플의 $\mathrm{DPPH}$ radical 소거능 측정 결과는 Table 2에, 반응표면 회귀분석은 Table 3에 제시하였다. 쑥 조청(A)과 당침마늘(B) 혼합물의 $\mathrm{DPPH}$ radical 소거능 측정 결과, $60.05-84.47 \%$ 범위를 보였는데, 8번 샘 플(쑥 조청2, 당침마늘2)이 $84.47 \%$ 로 가장 높았고, 7 번 샘플(쑥 조 청1, 당침마늘1)이 $60.05 \%$ 로 가장 낮게 나타났다. 독립변수가 각 각 작용하여 선형효과만 존재하는 linear model이 선정되었고, 결 정계수 $\mathrm{R}^{2}$ 값은 0.9177 로 모델에 대한 높은 신뢰도를 보였으며, $p<0.0007$ 로 $5 \%$ 이내에서 유의적인 결과를 보여 모델에 대한 적합 성이 인정되었다. Figure 8에 제시된 perturbation plot에서 쑥 조 청(A)과 당침마늘(B)의 함량이 증가할수록 $\mathrm{DPPH}$ radical 소거능이 우수하였고, 회귀식에 따라 쑥 조청(A)보다 당침마늘(B)의 첨가량이 $\mathrm{DPPH}$ radical 소거능에 더 큰 영향을 미치는 것으로 나타났다.

Jeong et al. (2015)은 마늘의 숙성 기간이 DPPH radical 소거능 증가에 영향을 미치는 것으로 보고하였는데, 본 연구에서 혼합물의 $\mathrm{DPPH}$ radical 소거능이 높아진 것은 당침마늘의 숙성 기간에 기인 한 것으로 보인다. 또한 Bang et al. (2014) 연구에서 쑥 분말 첨가 량이 증가할수록 DPPH radical 소거능의 유의적 증가를 보고하였는 데, 이는 본 연구 결과와 유사하였다.

\section{4) ABTS radical 소거능}

ABTS radical 소거능은 potassium persulfate와의 반응으로 인 해 생성된 ABTS 유리 라디칼이 추출물 내의 항산화 물질에 의해 제 거되어, 라디칼 특유의 색인 청록색이 탈색되는 것을 이용하여 측정 할 수 있다(Lee \& Ryu, 2019). RSM에 의해 설계된 쑥 조청과 당침
마늘 혼합물 11개 샘플의 ABTS radical 소거능 측정 결과는 Table 2 에, 반응표면 회귀분석은 Table 3 에 제시하였다. 쑥 조청(A)과 당침 마늘(B) 혼합물의 ABTS radical 소거능 측정 결과, $57.39-82.55 \%$ 범위를 보였는데, 8 번 샘플(쑥 조청2, 당침마늘2)이 $82.55 \%$ 로 가 장 높았고, 10 번 샘플(쑥 조청2, 당침마늘1.5)이 57.39\%로 가장 낮게 나타났다. 독립변수가 각각 작용하여 선형효과만 존재하는 linear Model이 선정되었고, 결정계수 $\mathrm{R}^{2}$ 값은 0.9850 로 모델에 대 한 높은 신뢰도를 보였으며, $p<0.0001$ 로 $5 \%$ 이내에서 유의적인 결 과를 보여 모델에 대한 적합성이 인정되었다. Figure 9 에 제시된 perturbation plot에서 쑥 조청(A)과 당침마늘(B)의 함량이 증가할 수록 ABTS radical 소거능이 우수하였고, 회귀식에 따라 쑥 조청(A) 보다 당침마늘(B)의 첨가량이 ABTS radical 소거능에 더 큰 영향을 미치는 것으로 나타났다.

Lee et al. (2010)의 연구에 의하면 생마늘에 비해 열처리한 마늘 에서 항산화 효능이 상승되었고, 갈변 물질이 많이 생성될수록 효능 이 더 증가하였으며, 마늘의 숙성기간과 정도에 따라 ABTS radical 소거능은 차이가 나는 것으로 보고하였다. 또한 Choi et al. (2006) 의 연구에서 쑥 추출물은 페놀화합물 함량에 비례하여 DPPH 및 ABTS radical 소거능이 높아진다고 하였는데, 본 연구에서도 쑥 조 청과 당침마늘 함량이 증가할수록 혼합물의 항산화 활성이 높아진 것을 알 수 있었다.

\section{RSM을 이용한 쑥 조청과 당침마늘 혼합물의 최적화}

본 연구에서는 반응표면분석법을 이용하여 쑥 조청과 당침마늘 혼합물의 최적혼합비율을 도출하고자 하였으며, 종속변수 중 항산 화 관련 지표로 total polyphenol 함량, total flavonoid 함량, DPPH 


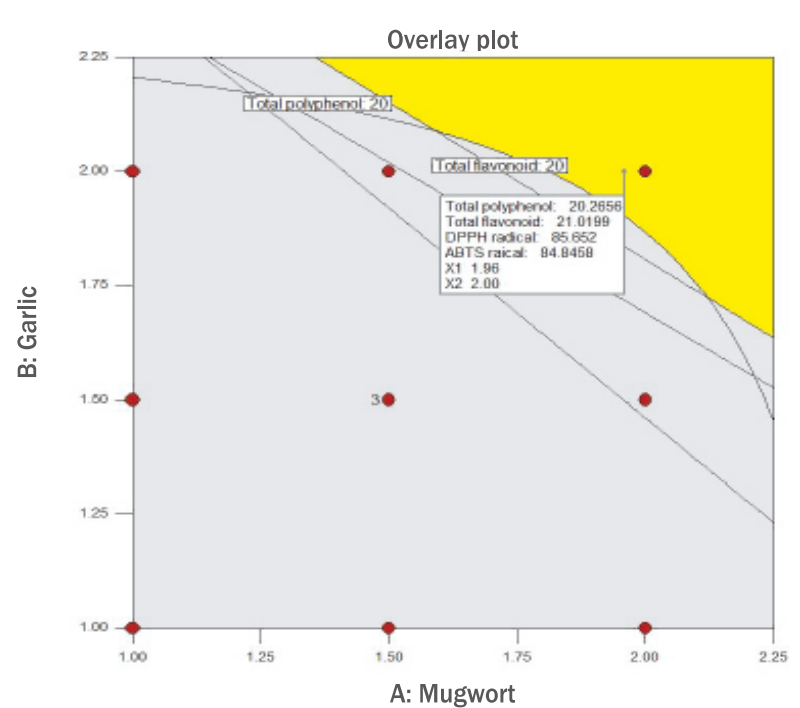

Figure 10. Overlay plot of optimized mugwort Chochung (A) and sugared garlic (B) on antioxidant activities.

radical 소거능, ABTS radical 소거능을 활용하였다. 쑥 조청과 당 침마늘의 배합 범위는 1-2로 설정하였고 항산화 활성이 최대로 발 현되는 최적혼합비율을 예측하고자 하였다. 최고의 desirability 를 나타낸 최적점을 선택하여 최적혼합비율을 산출한 후, 결과를 Figure 10에 제시하였다. 항산화 활성이 최대로 발현되는 최적혼합 비율은 쑥 조청(X1) 1.96, 당침마늘(X2) 2로 나타났으며, 이 때의 total polyphenol 함량은 $20.27 \mathrm{mg} \mathrm{TAE} / \mathrm{g}$, total flavonoid 함량은 $21.02 \mathrm{mg} \mathrm{QE} / \mathrm{g}$, DPPH radical 소거능은 $85.65 \%$, ABTS radical 소거능은 $84.85 \%$ 로 예측되었다.

\section{Conclusion}

본 연구의 목적은 쑥 조청, 당침마늘 단일물과 $1: 1$ 혼합물의 안전 성 여부를 알아보고, 반응표면분석법(RSM)을 이용하여 항산화 활 성이 최대로 발현되는 쑥 조청과 당침마늘 혼합물의 최적혼합비율 을 도출하고자 하는 것이다.

단일물(쑥 조청, 당침마늘)과 $1: 1$ 혼합물(쑥 조청과 당침마늘)에 대한 MTT assay 결과, $5000 \mu \mathrm{g} / \mathrm{mL}$ 까지 특이한 세포독성은 나타 나지 않았다.

또한 반응표면분석법(RSM)을 이용하여 쑥 조청과 당침마늘 혼합 물의 항산화 활성이 최대로 발현되는 최적혼합비율을 도출하기 위 해, 독립변수로 쑥 조청과 당침마늘, 종속변수로는 항산화 활성 지 표인 total polyphenol 함량, total flavonoid 함량, DPPH radical 소거능, ABTS radical 소거능으로 설정하였다. 그 결과, 항산화 활 성이 최대로 발현되는 최적혼합비율은 쑥 조청(X1) 1.96 , 당침마늘 (X2) 2 로 나타났으며, 이 때의 total polyphenol 함량은 $20.27 \mathrm{mg}$
$\mathrm{TAE} / \mathrm{g}$, total flavonoid 함량은 $21.02 \mathrm{mg} \mathrm{QE} / \mathrm{g}$, DPPH radical 소 거능은 $85.65 \%$, ABTS radical 소거능은 $84.85 \%$ 로 예측되었다.

따라서, 쑥과 마늘을 보완하여 제조한 쑥 조청과 당침마늘 혼합물 은 기능성 식품 소재로 사용하기에 매우 안전하면서 우수한 항산화 효능이 있는 것을 확인할 수 있었다. 또한 쑥 조청과 당침마늘 혼합 물의 항산화 효능이 최대로 발현되는 최적혼합비율을 도출하여, 향 후 안전한 천연 기능성 식품 소재로 그 이용가치가 높을 것으로 생 각된다.

\section{Author's contribution}

JSL as the first author, contributed to all aspects of analysis and experimental design, and wrote the manuscript. AJK as the second author, contributed to all the experimental design in detail and correcting the errors directly.

\section{Author details}

Jae-Seok Lee (Graduate student), Department of Alternative Medicine, Kyonggi University, 24, Kyonggidaero-9 gil, Seodaemun-gu, Seoul 03746, Korea; Ae-Jung Kim (Professor), Major of Nutrition Therapy, The Graduate School of Alternative Medicine, Kyonggi University, 24, Kyonggidaero-9 gil, Seodaemun-gu, Seoul 03752, Korea.

\section{References}

Ahn BM. What is in-jin-sook? Artemisia capillaris, Artemisia iwayomogi, and Artemisia annua. Clinical and Molecular Hepatology, 6: 548-551, 2000.

Bae SM, Park KJ, Shin DJ, Hwang YI, Lee SC. Preparation and characterization of Jochung with sweet persimmons. Journal of the Korean Society for Applied Biological Chemistry, 44: 88-91, 2001.

Bang BY, Kim KP, Rhee MS, Jeong EJ. Quality evaluations of cookies containing mugwort powder. The Korean Journal of Food and Nutrition, 27: 427-434, 2014.

Block E. The chemistry of garlic and onion. Scientific American, 252: 114-119, 1985.

Blois MS. Antioxidant determination by the use of a stable free radical. Nature, 181: 1199-1200, 1958.

Byun PH, Kim WJ, Yoon SK. Effects of extraction conditions on the functional properties of garlic extracts. Korean 
Journal of Food Science and Technology, 33: 507-513, 2001.

Carson JF. Chemistry and biological properties of onions and garlic. Food Reviews International, 3: 71-103, 1987.

Cavallito CJ, Buck JS. Alliin the antibacterial principle of Allium sativum. Determination of the chemical structure. Journal of the American Chemical Society, 66: 19521954, 1944.

Choi BB, Lee HJ, Bang SK. Studies on the volatile flavor components and biochemical characterizations of artemisia princeps and A. argyi. The Korean Journal of Food and Nutrition, 18: 334-340, 2005.

Choi DJ, Lee SJ, Kang MJ, Cho HS, Sung NJ, Shin JH. Physicochemical characteristics of black garlic (Allium sativum L.). Journal of Food Science and Nutrition, 37: 465-471, 2008.

Choi JH, Park GS. Study on utilization and perception of jochung. Journal of the East Asian Society of Dietary Life, 25: 979-989, 2015.

Choi IK, Lee JH. Quality characteristics of Yanggaeng incorporated with mugwort powder. The Korean Society of Food Science and Nutrition, 42: 313-317, 2013.

Choi YM, Chung BH, Lee JS, Cho YG. The antioxidant activities of Artemisia spp. collections. The Korean Society of Crop Science, 51: 209-214, 2006.

Chu CY, Tseng TH, Hwang JM, Chou FP, Wang CJ. Protective effects of capillarisin on tert-butylhydroperoxide-induced oxidative damage in rat primary hepatocytes. Archives of Toxicology: Archiv fur Toxikologie, 73: 263-268, 1999.

Chun HJ, Ahn BY, Han JH, Woo WH. Inhibitory effects of crude polysaccharide of water extract of Artemisia iwayomogi kitamura on melanin biosynthesis. Yakhak Hoeji, 45: 701-707, 2001.

Davis WB. Determination of flavanones in citrus fruits, Analytical Chemistry, 19: 476-478, 1947.

Drachenberg CB, Papadimitriou JC, Hirsch HH, Wali R, Crowder C, Nogueira J, Cangro CB, Mendley S, Mian A, Ramos E. Histological patterns of polyomavirus nephropathy correlation with graft outcome and viral load. American Journal of Transplantation, 4: 20822092, 2004.

Fellegrin N, Roberta R, Min Y, Catherine RE. Screening of dietary carotenoids and carotenoid-rich fruit extracts for antioxidant activities applying 2,2'-azinobis(3- thylenebenzothiazoline-6-sulfonic acid) radical cation decolorization assay. Methods in Enzymology, 299: 379389, 1998.

Han JS, Yi DH. Effects of pine needles fermentation extracts on antioxidant activity and inhibition of melanin synthesis. Asian Journal of Beauty and Cosmetology, 10: 619-624, 2012.

Han SB, Lee CW, Jeon YJ, Hong ND, Yoo ID, Yang KH, Kim HM. The inhibitory effect of polysaccharides isolated from phellinus linteus on tumor growth and metastasis. Immunopharmacology, 41: 157-164, 1999.

Jacobsen JV, Bernhard RA, Mann LK, Saghir AR. Infrared spectra of some asymmetric disulfides produced by allium. Archives of Biochemistry and Biophysics, 104: 473-477, 1964.

Jaggi JS, Seshan SV, Mcdevitt MR, La PK, Sgouros G, Scheinberg DA. Renal tubulointerstitial changes after internal irradiation with alpha-particle-emitting actinium daughters. Journal of the American Society of Nephrology, 16: 2677-2689, 2005.

Jain RC, Vyas CR. Garlic in alloxan-induced diabetic rabbits. The American Journal of Clinical Nutrition, 28: 684-685, 1975.

Jang EK, Seo JH, Lee SP. Physiological activity and antioxidative effects of aged black gaelic (Allium sativum L.) extract. Korean Society of Food Science and Technology, 40: 443-448, 2008.

Jang KH, Park HW, Lee DJ. Evaluation of antioxidant, anticancer and tyrosinase inhibition activities in Labiatae herb plants. The Journal of the Korean Society of International Agriculture, 23: 81-88, 2011.

Jeong H, Kim YS, Park PJ, Choi UK, Jeong JH, Lee US, Choi WS. Development of functional mixed drink using extract of Hericium erinacium cultivated with Artemisia capillaris and black garlic. Korean Journal of Food and Nutrition, 27: 751-759, 2014.

Jeong YS, Hwang KA, Kim GR, Song J, Noh GM, Hwang IG. Effects of the aging conditions on the quality characteristics of garlic. Korean Journal of Food and Nutrition, 28: 745-751, 2015.

Jung EY, Lee HS, Oh YH, Son HS, Suh HJ. Physicochemical properties of Jelly prepared with garlic. Journal of the East Asian Society of Dietary Life, 19: 627-634, 2009.

Jung YH, Han JS, Kim AJ. Quality evaluation and antioxidant 
activity of inner beauty tea prepared from roasted lotus root and burdock. Asian Journal of Beauty and Cosmetology, 17: 235-245, 2019.

Kim HJ, Lee JH. Quality Changes of Gochujang incorporated with strawberry puree during aging. Food Engineering Progress, 13: 110-116, 2009.

Kim HT, Kim JW, Lim MK, Yea SG, Jang KH, Oh TH, Lee KW. Antimicrobial effects of Artemisia capillaris extracts on the pathogenic bacteria in vitro. Journal of Veterinary Clinics, 24: 130-136, 2007.

Kim JY, Park KW, Yang HS, Cho YS, Jeong CH, Shim KH, Yee ST, Seo KI. Anticancer and immuno-activity of methanol extract from onion Kochujang. Korean Journal of Food Preservation, 12: 173-178, $2005 a$.

Kim KJ, Do JR, Kim HK. Antimicrobial, antihypertensive and anticancer activities of garlic extracts. Food Science and Biotechnology, 37: 228-232, 2005b.

Kim MR, Kim JH, Kim MR, Kang MH, Lee MS, Song HN, Park EJ, Lee JM. Health functional food, Powerbook, Goyang, pp1-352, 2015.

Kim ZH. Reinterpretaion of ungnyeo through eurasian bear worship and mugwort and garlic from dangun myth. The Korean Folklore, 67: 31-58, 2018.

Kwon SK. Organosulfur compounds from allium sativum and physiological activities. Biomolecules \& Therapeutics, 11: 8-32, 2003.

Lee SD, Park HH, Kim DW, Bang BH. Bioactive constituents and utilities of Artemisia sp. as medicinal herb and foodstuff. Journal of the Korean Society of Food Science and Nutrition, 13: 490-505, 2000.

Lee SJ, Shin JH, Kang MJ, Jung WJ, Ryu JH, Kim RJ, Sung NJ. Antioxidants activity of aged red garlic. Journal of Life Science, 20: 775-781, 2010.

Lee YS, Ryu MJ. Antioxidant effects of Cinnamomum cassia bark extract and its effectiveness as a cosmetics ingredient. Asian Journal of Beauty and Cosmetology, 17: 69-80, 2019.

Liotta LA. Tumor invasion and metastases--role of the extracellular matrix: rhoads memorial award lecture. Cancer Research, 46: 1-7, 1986.

Markowitz GS, Radhakrishnan J, Kambham N, Valeri AM, Hines WH, D'Agati VD. Lithium nephrotoxicity: a progressive combined glomerular and tubulointerstitial nephropathy. Journal of the American Society of
Nephrology, 11: 1439-1487, 2000.

Pal S, Bhattacharyya S, Choudhuri T, Datta GK, Das T, Sa G. Amelioration of immune cell number depletion and potentiation of depressed detoxification system of tumor-bearing mice by curcumin. Cancer Detection and Prevention, 29: 470-478, 2005.

Park YH, Park SJ, Han GJ, Choe JS, Lee JY, Kang MS. Quality characteristics of pre-processed garlic during storage according to storage temperature. Journal of the Korean Society of Food Science and Nutrition, 41: 994-1001, 2012.

Peters RL, Afroudakis AP, Tatter D. The changing incidence of association of hepatitis $\mathrm{b}$ with hepatocellular carcinoma in California. American Journal of Clinical Pathology, 68: 1-10, 1977.

Powers SK, Nelson WB, Hudson MB. Exercise-induced oxidative stress: cause and consequences. Free Radical Biology and Medicine, 51: 942-992, 2010.

Ram BP, Hart RJ, Pestka JJ. Application of Elisa to retail survey of aflatoxin B1 in peanut butter. Journal of Food Protection, 49: 792-798, 1986.

Rho SN, Han JH. Cytotoxicity of garlic and onion methanol extract on human lung cancer cell lines. Journal of the Korean Society of Food Science and Nutrition, 29: 870874, 2000.

Scherer E. Neoplastic progression in experimental hepatocarcinogenesis. Biochimical et Biophysica Acta, 738: 219-236, 1984.

Seo KS, Yun KW. Antimicrobial activity and total polyphenol content of extracts from Artemisia capillaries Thunb. and Artemisia iwayomogi Kitam. used as injin. Korean Journal of Plant Resources, 24: 10-16, 2011.

Shashikanth KN, Basappa SC, Murthy VS. Studies on the antimicrobial and stimulatory factor of garlic(Allium sativum Linn). Journal of Food Science and Technology, 18: 44-47, 1981.

Shin HJ, Shin DH, Kwak YS, Choo JJ, Ryu CH. Sensory evaluation and changes in microflora and enzyme activities of red ginseng Kochujang. Journal of the Korean Society of Food Science and Nutrition, 28: 766772, 1999.

Singleton VL, Rossi JA. Colorimetry of total phenolics with phosphomolybdic-phosphotungstic acid reagents. American Journal of Enology and Viticulture, 16: 144- 
158, 1995.

Son HS, Hwang WI. A study on the cytotoxic activity of garlic (Allium sativum) extract against cancer cells. Journal of Nutrition and Health, 23: 135-147, 1990.

Song KJ, Hwang ES. Quality characteristics and antioxidant activities of sikhye added with Artemisia capillaris extracts. Journal of the Korean Society of Food Science and Nutrition, 45: 1630-1637, 2016.
Stoll A, Seebeck E. Chemical investigations on alliin, the specific principle of garlic. Advances in Enzymology and Related Areas of Molecular Biology, 11: 377-400, 1951.

Sung KC. A study on the pharmacetical and chemical characteristics of natural artemisia extract. Journal of the Korean Oil Chemists Society, 26: 51-59, 2009. 


\section{국문초록}

\section{반응표면분석을 이용한 항산화 활성 최적화를 위한 쑥 조청과 당침마늘 혼합비율 확립}

이재석 ${ }^{1}$, 김애정 $^{2 *}$

${ }^{1}$ 경기대학교 대체의학과, 서울, 한국

${ }^{2}$ 경기대학교 대체의학대학원 식품치료전공, 서울, 한국

목적: 본 연구의 목적은 쑥 조청, 당침마늘 단일물과 그 혼합물(1:1)의 안전성 여부를 알아보고, 반응표면분석법(RSM)을 이용하여 항산화 활성이 최대로 발현되는 쑥 조청과 당침마늘 혼합물의 최적혼합비율을 도출하고자 함이다. 방법: 단일물(쑥 조청, 당침마 늘)과 1:1혼합물(쑥 조청과 당침마늘)의 안전성 평가를 위해 MTT assay를 수행하였다. RSM에 의해 독립변수는 인진쑥 조청(X1), 당침마늘(X2)의 함량, 함량의 최소 및 최대 범위를 1-2로 설정하였다. 종속변수로는 total polyphenol 함량, total flavonoid 함량, $\mathrm{DPPH}$ radical 소거능, ABTS radical 소거능으로 설정하였다. 결과: 단일물(쑥 조청, 당침마늘)과 1:1혼합물(쑥 조청과 당침마늘)에 서 세포독성은 나타나지 않았다. 또한 RSM에 의해 도출한 항산화 활성이 최대로 발현되는 최적혼합비율은 쑥 조청(X1) 1.96, 당침 마늘(X2) 2 였으며, 이 때의 total polyphenol 함량은 $20.27 \mathrm{mg} \mathrm{TAE} / \mathrm{g}$, total flavonoid 함량은 $21.02 \mathrm{mg} \mathrm{QE} / \mathrm{g}$, DPPH radical 소거 능은 85.65\%, ABTS radical 소거능은 84.85\%로 예측되었다. 결론: 약용식물인 쑥과 마늘을 식품 자체로의 이용 확대를 위해 쑥 조 청과 당침마늘을 제조하였고, 그 혼합물과 더불어 안전성을 확인하였다. 그리고 RSM을 통해 항산화 활성이 최대로 발휘되는 최적 점도 구하였다. 향후 본 연구 결과가 안전성이 확보된 천연 기능성 식품 소재로 다양하게 활용되길 기대한다.

핵심어: 쑥, 마늘, MTT assay, 항산화, 반응표면분석법

\section{참고문헌}

권순경. 마늘의 유기유황성분과 생리활성. Biomolecules \& Therapeutics, 11: 8-32, 2003.

김기주, 도정룡, 김현구. 마늘 추출물의 향균, 항고혈압 및 항암활성. 한국식품과학회지, 37: 228-232, 2005.

김미리, 김정희, 김미라, 강명화, 이명숙, 송효남, 박은주, 이정민. 건강에 도움이 되는 기능성식품, 파워북출판사, 고양, pp109, 2015.

김재용, 박경욱, 양현숙, 조영숙, 정창호, 심기환, 이성태, 서권일. 양파고추장 메탄올추출물의 항암 및 면역활성. 한국식 품저장유통학회지, 12: 173-178, 2005.

김재희. 유라시아 곰 신앙과 단군신화의 쑥과 마늘을 통해 본 웅녀의 재해석. 한국민속학, 67: 31-58, 2018.

김홍태, 김주완, 임미경, 여상건, 장광호, 오태호, 이근우. 인진쑥 추출물의 병원성 세균에 대한 시험관내 항균효과. 한국 임상수의학회지, 24: 130-136, 2007.

김희정, 이준호. 딸기 퓌레를 첨가한 고추장의 숙성 중 품질변화. 산업 식품공학, 13: 110-116, 2009.

노숙령, 한지혜. 인체 폐암세포주에 대한 마늘과 양파 메탄올추출물의 세포독성. 한국식품영양과학회지, 29: 870-874, 2000.

박영희, 박수진, 한귀정, 최정숙, 이진영, 강민숙. 마늘의 유통 형태에 따른 저장 중 품질 특성. 한국식품영양과학회지, 41: 994-1001, 2012.

방병호, 김관필, 이문수, 정은자. 쑥 분말 첨가량에 따른 쿠키의 품질 평가. 한국식품영양학회지, 27: 427-434, 2014. 배성문, 박강주, 신동주, 황용일, 이승철. 단감을 이용한 조청의 제조 및 특성. 한국응용생명화학회지, 44: 88-91, 2001. 변평화, 김우정, 윤석권. 추출조건이 마늘 추출액의 기능성에 미치는 영향. 한국식품과학회지, $33: 507-513,2001$. 서경순, 윤경원. 인진(茵蔯)으로 쓰이는 사철쑥과 더워지기 추출물의 항미생물활성 및 total polyphenol함량. 한국자원식 물학회지, 24: 10-16, 2011. 
성기천. 천연 쑥 추출물의 약리 및 화학적 특성 연구. 한국응용과학기술학회지, 26: 51-59, 2009.

손흥수, 황우익. 마늘중 지용성 성분의 암세포증식 억제효과 연구. Journal of Nutrition and Health, 23: 135-147, 1990.

송금자, 황은선. 인진쑥 추출물을 첨가하여 제조한 식혜의 품질 특성 및 항산화 활성. 한국식품영양과학회지, $45: 1630-$ 1637, 2016.

손경현, 임재각, 공운영, 박지용. 고압처리에 의한 Alliinase의 불활성화가 마늘의 풍미에 미치는 영향. 한국식품과학회지,

28: 593-599, 1996.

신현주, 신동화, 곽이성, 주종재, 유정희. 홍삼첨가 고추장의 관능적 특성 및 미생물과 효소력의 변화. 한국식품영양과학회 지, 28: 766-772, 1999.

안병민. 인진쑥(茵蔯蒿)이란 무엇인가? 사철쑥(Artemisia capillaris), 더워지기(Artemisia iwayomogi)와 개똥쑥

(Artemisia annua). 대한간학회지, 6: 548-551, 2000.

이성동, 박홍현, 김동원, 방병호. 쑥(艾)의 생리활성 물질과 이용. 한국식품영양학회지, 13: 490-505, 2000.

이수정, 신정혜, 강민정, 정우재, 류지현, 김라정, 성낙주. 숙성 홍마늘의 생리활성. 한국생명과학회지, 20: 775-781, 2010.

이영숙, 유민정. 계피 추출물의 항산화 효과 및 화장품소재의 응용. 아시안뷰티화장품학술지, 17: 69-80, 2019.

장가희, 박혜원, 이동진. 꿀풀과 허브 식물의 항산화, 항암 및 Tyrosinase 저해활성 검정. 한국국제농업개발학회지, 23:

81-88, 2011.

장은경, 서지현, 이삼빈. 숙성에 의해 제조된 흑 마늘 추출물의 생리학적 활성 및 항산화 효과. 한국식품과학회지, 40 : 443-448, 2008.

정연희, 한정순, 김애정. 로스팅한 연근과 우엉을 이용한 이너 뷰티 차의 항산화 활성과 품질 평가. 아시안뷰티화장품학술 지, 17: 235-245, 2019 .

정윤숙, 황경아, 김가람, 송진, 노건민, 황인국. 숙성조건이 마늘의 품질특성에 미치는 영향. 한국식품영양학회지, 28 : $745-751,2015$.

정은영, 이현순, 오윤호, 손흥수, 서형주. 마늘을 이용하여 제조한 젤리의 이화학적 품질 특성. 동아시아식생활학회지, $19:$ 627-634, 2009

정헌, 김연숙, 박표잠, 최웅규, 정재현, 이웅수, 최원석. 인진쑥을 기질로 한 노루궁뎅이버섯 균사체 배양물과 흑마늘을 이 용한 기능성 혼합음료 개발. 한국식품영양학회지, 27: 751-759, 2014

천현자, 안병용, 한종현, 우원홍. 인진쑥 물추출물의 조다당제에 의한 Melanin 생성억제 효과. 약학회지, 45: 701-707, 2001.

최덕주, 이수정, 강민정, 조희숙, 성낙주, 신정혜. 흑마늘의 이화학적 특성. 한국식품영양과학회지, 37: 465-471, 2008. 최병범, 이혜정, 방선권. 강화쑥의 생화학적 특성 및 휘발성 향기성분에 관한 연구. 한국식품영양학회지, 18: $334-340$, 2005.

최인경, 이준호. 쑥 분말을 첨가한 양갱의 품질특성. 한국식품영양과학회지, 42: 313-317, 2013. 최용민, 정봉환, 이준수, 조용구. 쑥 수집종의 항산화력. 한국작물학회지, 51: 209-214, 2006. 최정희, 박금순. 조청의 이용실태 및 선호도 연구. 동아시아식생활학회지, 25: 979-989, 2015. 한정선, 이동희. 솔잎 발효액의 항산화 활성 및 멜라닌 생성 억제 효과. 아시안뷰티화장품학술지, 10: 619-624, 2012. 


\section{中文摘要}

\section{利用响应曲面法（RSM）优化艾蒿造淸和糖蒜的抗氧化活性的最佳混合比例}

李在碩 ${ }^{1}$, 金愛貞 ${ }^{2 *}$

1京畿大学代替医疗学科, 首尔, 韩国

2京畿大学代替医疗大学院食品治疗学科, 首尔, 韩国

目的：研究艾蒿造淸和糖大蒜（单一化合物）以及两者的混合物（1：1）的安全性，并利用RSM找到该混合物的 最佳混合比例, 从而可以最大程度地提高抗氧化活性。方法: 进行了MTT分析, 以评估每种单一化合物, 艾蒿造 淸和加糖大蒜以及 $1: 1$ 混合物的安全性。自变量将艾蒿造淸设置为 X1, 将加糖大蒜的分析方法设置为X2, 将 $R S M$ 的最小和最大范围设置为 1 至2。并且, 因变量是总多酚测定, 总类黄酮测定, DPPH自由基清除能力和ABTS自 由基清除能力。结果: 艾蒿造淸和加糖大蒜以及 $1: 1$ 混合物均未显示任何细胞毒性。同样，我们发现可以使抗氧 化剂活性最大化的混合物的最佳混合比例是艾蒿造淸 (X1) 为 1.96 , 加糖大蒜 (X2) 为 2 , 源自 $R S M$ 。在最佳条 件下，预测的特征值为：总多酚测定值为 $20.27 \mathrm{mg} T A E / g$, 总黄酮含量测定为 $21.02 \mathrm{mg} \mathrm{QE} / \mathrm{g}$, DPPH自由基 清除能力为 $85.65 \%$, ABTS自由基清除能力为 $84.85 \%$ 。结论: 我们准备了艾蒿造淸和加糖大蒜, 以扩艾蒿造淸 和大蒜（药用植物）的用途，并确认了其混合物的安全性。同样，具有最大抗氧化剂活性的最佳点来自RSM。 我们希望这项研究可以用作具有安全性的天然功能性食品成分。

关键词: 艾蒿，大蒜，MTT法，抗氧化活性，响应曲面法 
